Original Research Article

\title{
A comparative evaluation of intravenous dexmedetomidine and oral clonidine in attenuating the rise in intra ocular pressure
}

\author{
Yadhuraj M. K.*, Somasekharam P., Vinay D. M., Akhil Rao U. K.
}

Department of Anaesthesia, MVJ Medical College and RH Hoskote, Bangalore, Karnataka, India

Received: 09 September 2017 Accepted: 16 September 2017

*Correspondence to:

Dr. Yadhuraj M. K.,

Email: dryadurajgowda@ gmail.com

Copyright: (C) the author(s), publisher and licensee Medip Academy. This is an openaccess article distributed under the terms of the Creative Commons Attribution NonCommercial License, which permits unrestricted noncommercial use, distribution, and reproduction in any medium, provided the original work is properly cited.

\begin{abstract}
Background: Administration of Suxamethonium, laryngoscopy and intubation is associated with rise in intraocular pressure (IOP). The need to attenuate rise in IOP is of utmost importance, especially in patients with perforating injury of the eyeball. The present study was undertaken to compare the effectiveness of intravenous Dexmedetomidine $0.4 \mu \mathrm{g} / \mathrm{kg}$ and oral Clonidine $3 \mu \mathrm{g} / \mathrm{kg}$ in attenuating the rise in IOP following administration of suxamethonium, laryngoscopy and intubation.
\end{abstract}

Methods: 150 patients of ASA I or II, aged between 18-60 years, who were posted for elective non-ophthalmic surgery requiring general anaesthesia were included in this study. Patients were randomly divided into 3 groups with 50 patients in each group. Group-D: Received $0.4 \mu \mathrm{g} / \mathrm{kg}$ IV dexmed in $10 \mathrm{ml}$ sterile water, over $10 \mathrm{~min}$ before induction. Group-C: Received $3 \mu \mathrm{g} / \mathrm{kg}$ oral clonidine two hours prior to surgery. Group-S: Control group.

Results: IOP, MAP, and HR were recorded at baseline, before induction, after induction, $1 \mathrm{~min}, 3 \mathrm{~min}$ and $5 \mathrm{~min}$ after administration of suxamethonium. Although Suxamethonium laryngoscopy and intubation increased IOP in all the 3 groups there was significant reduced rise in IOP noted in dexmed group and clonidine group compared to study group $(\mathrm{p}=<0.001)$. Furthermore, patients in dexmed group had lesser rise in IOP compared to clonidine group $(\mathrm{p}=<0.001)$.

Conclusions: We concluded that both intravenous dexmedetomidine $0.4 \mu \mathrm{g} / \mathrm{kg}$ and oral clonidine $3 \mu \mathrm{g} / \mathrm{kg}$, significantly attenuated the rise in IOP associated with administration of suxamethonium, laryngoscopy and intubation. However intravenous dexmedetomidine proved better than oral clonidine in attenuating the rise in IOP.

Keywords: Intravenous dexmedetomidine, Intraocular pressure, Intubation, Laryngoscopy, Oral clonidine, Suxamethonium

\section{INTRODUCTION}

Anaesthesiology and ophthalmology have made remarkable advance in the past three decades. The development of stable intravenous and inhalational anaesthetic agents, muscle relaxants and monitoring devices provide safe environment for patients. Although many ophthalmic procedures can be performed under local anaesthesia, general anaesthesia is required for children, patients who are mentally challenged and with senility, tremors and deafness, for certain procedures and patients preference.
Control of intraocular pressure is very vital to the operative outcome in an ophthalmic surgery. In patients posted for nonophthalmic surgeries if the intraocular pressure is already elevated, a further increase can precipitate an acute attack of glaucoma. ${ }^{1}$ Rise in the intraocular pressure can rupture blood vessels with subsequent hemorrhage which may lead to expulsion of the contents of the eyeball and permanent loss of vision. Patients who have sustained penetrating eye injury are challenging. We have to prevent further damage to the eye by avoiding an increase in the intraocular pressure and secure the airway by rapid sequence intubation as these cases come to emergency OT usually with full stomach. Various methods have been 
tried to attenuate the intraocular hypertensive response but none of the method has given consistent results. ${ }^{2}$

We conducted the study by using Dexmedetomidine and Clonidine which are $\alpha-2$ receptor agonists to reduce the rise in intraocular pressure following administration of suxamethonium, laryngoscopy and intubation.

\section{METHODS}

The study was conducted at MVJ Medical College and Research Hospital in the Department of Anaesthesiology, on patients who underwent various elective nonophthalmic surgeries between 18-60 years of age of either gender requiring General Anaesthesia with endotracheal intubation. Patients with predicted difficult airway, with IHD, heart blocks, on beta blockers and with glaucoma were excluded from the study. After approval from the ethical committee, Study was conducted on 150 ASA I and II patients scheduled for elective non ophthalmic surgery. Pre-anaesthetic check up was done one day prior to the surgery. The procedure of measuring IOP; intraocular pressure was explained to the patients and written informed consent was obtained for participation in study. All patients received Tab. Alprazolam $0.25 \mathrm{mg}$ and Tab. Ranitidine $150 \mathrm{mg}$ in the night before the day of surgery. Patients are randomly divided into 3 groups of 50 each, viz., Group (D) Dexmedetomidine, Group (C) Clonidine and Group (S) Control group. Patients in Group (C) received Oral tab Clonidine $(3 \mu \mathrm{g} / \mathrm{kg})$ with a sip of water 2 Hours prior to surgery. Patients in Group (D) received Intravenous Dexmedetomidine $(0.4 \mu \mathrm{g} / \mathrm{kg})$ diluted in $10 \mathrm{ml}$ sterile water over 10 minutes, 10 minutes before the induction. Group(S) Control group did not get any medication. 2 drops of $4 \%$ Xylocaine topical was instilled into eyes to anaesthetize cornea before recording of IntraOcular Pressure. Intraocular pressure, Heart rate, and Mean Arterial Pressure of all patients were recorded during preanaesthetic visit for basal reading. IOP was measured using Schiotz indentation tonometer.

Pre-induction Intra-ocular pressure, Heart rate, and Mean Arterial Pressure were recorded in all the 3 groups which show the effect of the drug on IOP. On the OT table inj. Glycopyrrolate $0.005 \mathrm{mg} / \mathrm{kg}$ (I.V) to the maximum of 0.2 mg was given. Patients were pre-oxygenated with $100 \%$ oxygen, induced with inj. thiopentone $5 \mathrm{mg} / \mathrm{kg}$ body weight. Intra-ocular Pressure, Heart rate, mean arterial pressure was recorded 30 seconds after induction which shows the effect of thiopentone on IOP. Then the patients received Inj. Suxamethonium $1.5 \mathrm{mg} / \mathrm{kg}$. Intra-ocular Pressure, Heart rate and Mean arterial pressure was recorded 1, 3 and 5 minutes after Suxamethonium. Intubation with endotracheal tube was done within 60 seconds after 1 min of Suxamethonium after first minutes IOP recording which shows the effect of Suxamethonium on IOP. Cases which required longer time (more than 60 seconds) to secure airway, were not included in the study. The $3^{\text {rd }}$ minute recording was post laryngoscopy and intubation showing its effect on IOP. Anesthesia was maintained with Nitrous oxide, Oxygen and Halothane. Fentanyl $2 \mu \mathrm{g} / \mathrm{kg}$ was used for analgesia and vecuronium as muscle relaxant. Side effects like bradycardia, hypotension, post operative nausea and vomiting were recorded.

\section{Statistical methods}

Descriptive and inferential statistical analysis has been carried out in the present study. Results on continuous measurements are presented on Mean \pm SD (Min-Max) and results on categorical measurements are presented in Number (\%). Significance is assessed at $5 \%$ level of significance. The following assumptions on data is made,

\section{Assumptions}

- Dependent variables should be normally distributed,

- Samples drawn from the population should be random,

- $\quad$ Cases of the samples should be independent.

Analysis of variance (ANOVA) has been used to find the significance of study parameters between three groups of patients.

\section{Significant figures}

- $\quad+$ Suggestive significance $(\mathrm{P}$ value: $0.05<\mathrm{P}<0.10)$

- $\quad *$ Moderately significant (P value: $0.01<\mathrm{P} \leq 0.05$ )

- $\quad * *$ Strongly significant ( $\mathrm{P}$ value: $\mathrm{P} \leq 0.01$ )

\section{Statistical software}

The Statistical software namely SAS 9.2, SPSS 15.0, Stata 10.1, MedCalc 9.0.1, Systat 12.0 and R environment ver.2.11.1 were used for the analysis of the data and Microsoft word and Excel have been used to generate graphs, tables etc.

\section{RESULTS}

It was a prospective randomized comparative and controlled three group study.

\section{Table 1: Age distribution of the patients in all the 3 groups.}

\begin{tabular}{|c|c|c|c|c|c|c|}
\hline \multirow{2}{*}{$\begin{array}{l}\text { Age in } \\
\text { years }\end{array}$} & \multicolumn{2}{|c|}{ Group S } & \multicolumn{2}{|c|}{ Group D } & \multicolumn{2}{|c|}{ Group C } \\
\hline & No & $\%$ & No & $\%$ & No & $\%$ \\
\hline $18-20$ & 5 & 10.0 & 8 & 16.0 & 4 & 8.0 \\
\hline $21-30$ & 15 & 30.0 & 18 & 36.0 & 22 & 44.0 \\
\hline $31-40$ & 15 & 30.0 & 14 & 28.0 & 16 & 32.0 \\
\hline $41-50$ & 8 & 16.0 & 7 & 14.0 & 7 & 14.0 \\
\hline $51-60$ & 7 & 14.0 & 3 & 6.0 & 1 & 2.0 \\
\hline Total & 50 & 100 & 50 & 100 & 50 & 100 \\
\hline Mean \pm SD & \multicolumn{2}{|c|}{$36.70 \pm 12.76$} & \multicolumn{2}{|c|}{$32.42 \pm 11.51$} & \multicolumn{2}{|c|}{$32.32 \pm 10.04$} \\
\hline
\end{tabular}


In group-S there were 20 Male and 30 Female patients. In group-D there were 24 Male and 26 Female patients. In group-C there were 22 Male and 28 Female patients.

The mean body weight in group-S was $56.94 \pm 13.79$, in group-D was $58.46 \pm 11.08$ and in group-C was $57.54 \pm 12.34$. All the 3 groups were comparable and there was no statistically significant difference with regards to mean age, gender and weight distribution.

- $\quad$ In group-S 22 patients (44\%) belong to ASA-I and 28 patients $(56 \%)$ belong ASA-II.

- In group-D 32 patients $(64 \%)$ belong to ASA-I and 18 patients $(36 \%)$ belong ASA-II.

- In group-C 36 patients (72\%) belong to ASA-I and 14 patients $(28 \%)$ belong ASA-II.

All the 3 groups had comparable ASA grade with maximum patients $(60 \%)$ belonged to ASA-I and (40\%) patients belonged to ASA-II.

Table 2: The inter-group comparison of IOP ( $\mathrm{mmHg}$ ) changes in the patients between group-S and group-D.

\begin{tabular}{|lll|l|}
\hline & Group S & Group D & P value \\
\hline Baseline & $16.65 \pm 0.95$ & $16.54 \pm 0.83$ & \\
\hline $\begin{array}{l}\text { Before } \\
\text { induction }\end{array}$ & $16.66 \pm 0.96$ & $15.76 \pm 0.99$ & $0.01^{*}$ \\
\hline $\begin{array}{l}\text { After } \\
\text { induction }\end{array}$ & $16.38 \pm 1.18$ & $15.53 \pm 1.48$ & $0.003^{* *}$ \\
\hline 1 min & $24.31 \pm 2.22$ & $18.12 \pm 1.87$ & $<0.001^{* *}$ \\
\hline 3 min & $25.69 \pm 3.38$ & $18.62 \pm 1.62$ & $<0.001^{* *}$ \\
\hline 5 min & $20.52 \pm 2.83$ & $17.01 \pm 1.25$ & $<0.001^{* *}$ \\
\hline
\end{tabular}

The mean basal IOP were comparable in all groups, group$\mathrm{S}$, group-D and group-C. There was a significant fall in IOP in group D, following administering Dexmedetomidine but group-C showed minimum fall in IOP from the base line values 2 hours after oral Clonidine administration. The mean basal IOP in group-D was $16.54 \pm 0.83$ and mean basal IOP in group-C was $16.92 \pm 0.89(\mathrm{p}=0.441) .0 .38 \mathrm{mmHg}$ reduction in IOP was noted in group-D after drug administration, compared to $0.1 \mathrm{mmHg}$ reduction in group- $\mathrm{C}$ compared to their baseline IOP values respectively $(\mathrm{p}=0.786)$. Highly significant fall in IOP noted in group-D and group-C 30 seconds after thiopentone induction compared to group-S (control group). $0.61 \mathrm{mmHg}$ reduction in IOP noted in group-D compared to $0.13 \mathrm{mmHg}$ reduction in group- $\mathrm{C}, 30$ seconds after thiopentone induction $(\mathrm{p}=0.538)$. The rise in mean IOP observed 1 minute 3 minutes and 5 minutes after Suxamethonium, laryngoscopy and intubation, in group-C was statistically highly significant compared to IOP in group-D $(\mathrm{p}=<0.001)$. Maximum rise in IOP noted at 3 minute interval time in all the 3 groups studied with respect to their baseline values.

Table 3: The inter-group comparison of IOP (mmHg) changes in the patients between group-S and group-C.

\begin{tabular}{|llll|}
\hline & Group S & Group C & P value \\
\hline Baseline & $16.65 \pm 0.95$ & $16.92 \pm 0.89$ & \\
\hline $\begin{array}{l}\text { Before } \\
\text { induction }\end{array}$ & $16.66 \pm 0.96$ & $15.82 \pm 1.00$ & $<0.001^{* *}$ \\
\hline $\begin{array}{l}\text { After } \\
\text { induction }\end{array}$ & $16.38 \pm 1.18$ & $15.79 \pm 1.06$ & $0.054+$ \\
\hline 1 min & $24.31 \pm 2.22$ & $19.84 \pm 2.29$ & $<0.001^{* *}$ \\
\hline 3 min & $25.69 \pm 3.38$ & $21.87 \pm 2.6$ & $<0.001^{* *}$ \\
\hline 5 min & $20.52 \pm 2.83$ & $18.65 \pm 1.6$ & $<0.001^{* *}$ \\
\hline
\end{tabular}

Table 4: The inter-group comparison of IOP ( $\mathrm{mmHg})$ changes in the patients between group-D and group-C.

\begin{tabular}{|llll|}
\hline & Group D & Group C & P value \\
\hline Baseline & $16.54 \pm 0.83$ & $16.92 \pm 0.89$ & 0.441 \\
\hline $\begin{array}{l}\text { Before } \\
\text { induction }\end{array}$ & $15.76 \pm 0.99$ & $15.82 \pm 1.00$ & 0.786 \\
\hline $\begin{array}{l}\text { After } \\
\text { induction }\end{array}$ & $15.53 \pm 1.48$ & $15.79 \pm 1.06$ & 0.538 \\
\hline 1 min & $18.12 \pm 1.87$ & $19.84 \pm 2.29$ & $<0.001^{* *}$ \\
\hline 3 min & $18.62 \pm 1.62$ & $21.87 \pm 2.6$ & $<0.001^{* *}$ \\
\hline 5 min & $17.01 \pm 1.25$ & $18.65 \pm 1.6$ & $<0.001^{* *}$ \\
\hline
\end{tabular}

Maximum rise in mean HR and MAP was noted at 3 minutes after Suxamethonium administration followed by laryngoscopy and intubation in all the 3 groups. The side effects like bradycardia and hypotension were noted between all the 3 groups and were not statistically significant $(\mathrm{p}=0.929)$.

Table 5: The inter-group comparison of MAP $(\mathrm{mmHg})$ and Mean heart rate changes in all the 3 groups.

\begin{tabular}{|lllllll|}
\hline & Group S & & Group D & & Group C \\
& MAP & Mean HR & MAP & Mean HR & MAP & Mean HR \\
\hline Baseline & $96.80 \pm 10.05$ & $84.22 \pm 21.53$ & $95.96 \pm 9.82$ & $88.46 \pm 18.66$ & $96.44 \pm 8.43$ & $86.36 \pm 11.88$ \\
\hline Before induction & $96.90 \pm 9.80$ & $83.22 \pm 21.53$ & $90.76 \pm 9.97$ & $78.50 \pm 17.17$ & $89.08 \pm 11.33$ & $77.04 \pm 18.48$ \\
\hline After induction & $95.92 \pm 9.87$ & $93.18 \pm 11.48$ & $88.98 \pm 10.06$ & $84.14 \pm 12.39$ & $88.42 \pm 9.66$ & $83.94 \pm 12.36$ \\
\hline $1 \mathrm{~min}$ & $120.22 \pm 23.82$ & $106.94 \pm 15.11$ & $108.32 \pm 15.56$ & $96.84 \pm 11.41$ & $108.08 \pm 18.93$ & $90.02 \pm 14.49$ \\
\hline $3 \mathrm{~min}$ & $125.64 \pm 17.72$ & $108.20 \pm 16.95$ & $113.66 \pm 16.46$ & $101.86 \pm 12.1$ & $117.98 \pm 15.94$ & $93.62 \pm 14.65$ \\
\hline $5 \mathrm{~min}$ & $107.42 \pm 13.37$ & $102.22 \pm 17.13$ & $100.58 \pm 12.53$ & $92.92 \pm 12.13$ & $105.64 \pm 16.03$ & $89.94 \pm 16.04$ \\
\hline
\end{tabular}




\section{DISCUSSION}

The need to attenuate rise in intraocular pressure is of utmost importance especially in perforating injury of the eye ball. These cases may present as emergency and often with full stomach. Rapid sequence intubation becomes mandatory, where suxamethonium is needed because of its rapid onset of action. However, administration of suxamethonium raises the intraocular pressure, endangering the expulsion of the contents of eye, if eye is perforated.

Laryngoscopy and Endotracheal intubation are employed for safe conduct of anaesthesia. Both Laryngoscopy and intubation are noxious stimuli and are associated with stress response leading to hypertension, tachycardia and rise in IOP. ${ }^{3}$ The rise in IOP is transient and may not be significant in otherwise normal individuals. But in patients with open globe injuries, it may result in expulsion of ocular contents, resulting in possible blindness.

Although Rocuronium, an intermediate acting nondepolarizing muscle relaxant provides good intubating conditions after 60-90 seconds and vecuronium within 120 seconds, it is not preferred in emergency and patients with anticipated difficult airway in our settings. ${ }^{4}$ Although it eliminates the muscle fasciculation and associated rise in IOP it will not reduce the response for laryngoscopy and intubation. Many methods of attenuating the rise in intraocular pressure have been tried with limited success. Some of the procedures are self-taming by administering small doses of suxamethonium before conventional dose and administration of small doses of non depolarizing muscle relaxants prior to administration of suxamethonium. ${ }^{5,6}$

Administration of lignocaine, fentany, esmolol, nifedipine, before administering Suxamethonium will reduce stress response to laryngoscopy and intubation but will not reduce the rise in IOP. Hence the drug, which can blunt both the increase in IOP and haemodynamic response to laryngoscopy and intubation without causing significant adverse effects are required. Dexmedetomidine and clonidine are two drugs which are $\alpha-2$ adrenergic agonists, which bestow the property of inhibiting steep rise in intraocular pressure following administration of suxamethonium, laryngoscopy and intubation.

As clonidine being less potent $(\alpha-1: \alpha-2=1: 220)$ compared to Dexmedetomidine $(\alpha-1: \alpha-2=1: 1620)$ in its agonism to $\alpha-2$ receptors, two different doses (equipotent doses) of these two drugs were selected for our study with two different routes of administration. The present study was under taken to study the effectiveness of intravenous dexmedetomidine at a dose of $0.4 \mu \mathrm{g} / \mathrm{kg}$ and oral clonidine at a dose of $3 \mu \mathrm{g} / \mathrm{kg}$ in attenuating the rise in intraocular pressure following administration of suxamethonium, laryngoscopy and intubation.
In 1968 Miller et al, employing indentation tonometry, reported that dtubocurarine and gallamine pre-treatment inhibited succinylcholine-induced rise in IOP. ${ }^{6}$ In 1979 Verma et al utilizing indentation tonometry, claimed that a $10 \mathrm{mg}$ "selftaming" dose of succinylcholine prevented a subsequent rise in intraocular pressure. ${ }^{3}$ Subsequently in 1980 Myers in a controlled study using applanation tonometry refuted Verma's claim. ${ }^{7}$ In 1979 smith et al claimed intravenous lidocaine $1-2 \mathrm{mg} / \mathrm{kg}$ pre-treatment may attenuate the haemodynamic response to laryngoscopy but such pre-treatment is ineffective in preventing the rise in intraocular pressure following succinylcholine and intubation. ${ }^{8}$ In 1981 Cunningham et $\mathrm{al}$, claimed that $0.1 \mathrm{mg} / \mathrm{kg}$ diazepam pre-treatment diminished the subsequent rise in intraocular pressure following succinylcholine and tracheal intubation while Cook $\mathrm{JH}$ et al, reported that $0.05 \mathrm{mg} / \mathrm{kg}$ diazepam pretreatment failed to prevent succinylcholine induced rise in IOP..$^{9,10}$ In 1989 Indu et al, suggested that sublingual nifedipine is effective in attenuating the IOP response after succinylcholine administration, laryngoscopy and intubation. ${ }^{11}$ In 1993 Kelly et al, studied the effect of succinylcholine in 15 patients undergoing elective enucleation, after all the extraocular muscles were detached in the diseased eye to that of the normal eye that had the extraocular muscles attached. Baseline IOP was comparable in both eyes. After succinylcholine administration, there was an increase in IOP which peaked at 90 seconds and returned to baseline after 5 mins. They found that there was a significant rise in IOP in both eyes but there was no major difference in the peak intraocular pressure between the normal eye and the diseased eye. (25.2 Vs 24.7). They concluded that the extraocular muscles do not contribute to the rise in IOP after succinylcholine administration. ${ }^{12}$

In 2008, Mowafi et al, conducted a double blind randomized controlled study in 40 patients undergoing elective non-ophthalmic surgery under general anaesthesia, to investigate the effect of dexmedetomidine premedication on intraocular pressure changes after succinylcholine and endotracheal intubation. They concluded that inj. Dexmedetomidine premedication 10 mins before induction blunted the rise in IOP caused by succinylcholine and intubation with haemodynamic stability. ${ }^{13}$ In 2011 Chandan Kumar Pal, Manjushree Ray et al, studied the effect of dexmedetomidine premedication in two doses on changes in IOP following administration of succinylcholine and endotracheal intubation in 66 adult patients. The authors concluded that dexmedetomidine prevents the rise in IOP associated with succinylcholine and intubation. However, haemodynamic stability is better maintained with a lower dose $(0.4 \mu \mathrm{g} / \mathrm{kg})$ of dexmedetomidine. Hence, it is desirable for prevention of rise in IOP. ${ }^{14}$

In 1988 Ghignone $\mathrm{M}$ et al, studied the effect of clonidine on intraocular pressure and cardiovascular response to laryngoscopy and endotracheal intubation. Oral clonidine $5 \mu \mathrm{g} / \mathrm{kg}$ was given $90 \mathrm{~min}$ prior to induction. It was found 
that oral Clonidine premedication resulted in adequate sedation, effective blunting of intraocular pressure and haemodynamyic responses to laryngoscopy and intubation. ${ }^{15}$ In 2002 Kashefi et al, observed the effect of oral clonidine and intravenous lidocaine on intraocular pressure following laryngoscopy and intubation. They found that difference in intraocular pressure was statistically significant between the groups. ${ }^{16}$ In 2007 Zahedi et al, compared the effects of oral clonidine $(3 \mu \mathrm{g} / \mathrm{kg})$ and diazepam $(0.15 \mathrm{mg} / \mathrm{kg})$ as premedications on IOP and haemodynamics after induction, succinylcholine and intubation. They observed that patients in clonidine group had lower IOP than diazepam group at all time and the difference between the two groups was significant at 5 minutes after intubation. ${ }^{17}$

Our study correlates with studies done by Chandan Kumar Pal et al and Mowafi et al, Zahedi et al and Ghignone $\mathrm{M}$ et al, who also found decrease in IOP from the baseline values following study drug administration. The rise in IOP in control group was above base line after intubation and even at 6th minute correlates with our study. But there was no significant rise in IOP above base line after intubation in Dexmedetomidine group and Clonidine group in studies done. ${ }^{18}$ But in our study, in group-D and group-C, IOP raised above base line values after intubation.

\section{CONCLUSION}

We concluded that intravenous Dexmedetomidine and oral Clonidine attenuated the rise in IOP. However intravenous dexmedetomidine at a dose of $0.4 \mu \mathrm{g} / \mathrm{kg}$ body weight administered IV over $10 \mathrm{~min}$ before induction, proved to be better than oral clonidine at a dose of $3 \mu \mathrm{g} / \mathrm{kg}$ administered with sips of water, 2 hours prior to induction, in attenuating the rise in IOP and achieving a better hemodynamic stability.

Funding: No funding sources

Conflict of interest: None declared

Ethical approval: The study was approved by the Institutional Ethics Committee

\section{REFERENCES}

1. Murphy DF. Anaesthesia and intraocular pressure. Anesth Analg. 1985;64:520-30.

2. Mirakhur RK. Intraocular pressure changes during rapid sequence induction of anaesthesia; Comparision of propofol and thiopentone in combination with vecuronium. Br. J. Anaesth. 1988;60:379-83.

3. Verma RS. Self-taming of succinylcholine induced fasciculations and iop. Anaesthesiology. 1979;50(3)245-7.

4. Miller RD, Wary WL, Mickey RF. Inhibition of succinylcholine induced intraocular pressure by nondepolarizing muscle relaxants. Anaesthesiology. 1968;29:123-6.
5. Myers EF, Singer P, Otto A. A controlled study of the effect of succinylcholine self-taming on intraocular pressure. Anesthesiology. 1980;53:72-4.

6. Smith RB, Babinski M, Leano N. The effect of lidocaine on succinylcholine induced rise in intraocular pressure. Can Anaesth Soc J. 1979;26:4823.

7. Cunningham AJ, Albert O, Cameron J, Watson AG. The effect of intravenous Diazepam on rise in intraocular pressure following succinylcholine. Can Anaesth Soc J. 1981;28:591-6.

8. Feneck RO, Cook JH. Failure of diazepam to prevent the Suxamethonium induced rise in intraocular pressure. Anaesthesia. 1983;38:120-7.

9. Indu B, Batra YK, Puri GD, Singh H. Nifedipine attenuates the intraocular pressure response to intubation following succinylcholine. Canadian Journal of Anesthesia/Journal canadien d'anesthésie. 1989 May 1;36(3):269-72.

10. Kelly RE, Dinner M, Turner LS, Haik B, Abramson DH, Daines P. Succinylcholine increases intraocular pressure in the human eye with the extraocular muscles detached. Anaesthesiology. 1993;79:948-52.

11. Mowafi HA, Aldossary N, Ismail SA, Alqahtani J. Effect of Dexmedetomidine premedication on the intra ocular pressure changes after succinylcholine and intubation. Br Journal of Anesth. 2008;100:485-9.

12. Pal CK, Ray M, Sen A, Hajra B, Mukherjee D, Ghanta AK. Changes in intraocular pressure following administration of suxamethonium and endotracheal intubation: influence of dexmedetomidine premedication. Indian journal of anaesthesia. 2011 Nov;55(6):573.

13. Ghignone $M$, Noe $C$, Calvillo O, Quintin L. Anesthesia for ophthalmic surgery in the elderly: the effects of clonidine on intraocular pressure, perioperative hemodynamics, and anesthetic requirement. Anesthesiology. 1988 May;68(5):70716.

14. Kashefi P, Hashemi J. Effect of oral clonidine and intravenous lidocaine on intraocular pressure following laryngoscopy and intubation. Journal of Research in Medical Sciences. 2002;7(2).

15. Zahedi H, Nikooseresht M, Rahro-Taban M. The effect of oral Clonidine pretreatment on intraocular pressure and hemodynamic stability after succinylcholine injection and intubation in cataract surgery. Medical Journal of the Islamic Republic of Iran. 2007 Aug;21(2):111-4.

16. Jaakola ML, Ali-Melkkilä T, Kanto J, Kallio A, Scheinin H, Scheinin M. Dexmedetomidine reduces intraocular pressure, intubation reponses and anaesthetic requirements in patients undergoing ophthalmic surgery. BJA: British Journal of Anaesthesia. 1992 Jun 1;68(6):570-5.

17. Kumar A, Bose S, Bhattacharya A, Tandon OP, Kundra P. Oral Clonidine premedication for elderly patients undergoing intraocular surgery. Acta Anaesthesiol Scand. 1992;36:159-64. 
18. Kumar CP, Ray M. Studied the influence of dexmedetomidine premedication on Changes in intraocular pressure following administration of suxamethonium and endotracheal intubation. Indian $\mathbf{J}$ Anaesth. 2011;55:573-7.
Cite this article as: Yadhuraj MK, Somasekharam $\mathrm{P}$, Vinay DM, Rao AUK. A comparative evaluation of intravenous dexmedetomidine and oral clonidine in attenuating the rise in intra ocular pressure. Int $\mathbf{J}$ Basic Clin Pharmacol 2017;6:2528-33. 